Available online on 15.3.2018 at http://ujpr.org
Universal Journal of Pharmaceutical Research
An International Peer Reviewed Journal
Open access to Pharmaceutical research is an open access article distributed under the terms of the Creative Commons Attribution-Non
Commercial Share Alike 4.0 License which permits unrestricted non commercial use,
provided the original work is properly cited
Volume 3, Issue 1, 2018

\title{
THE EVALUATION OF THE POSITION OF HEALTH AND SAFETY SYSTEM IN MULTI-LEVEL STRATEGIC MANAGEMENT OF STAFFS IN SHIRAZ UNIVERSITY OF MEDICAL SCIENCE

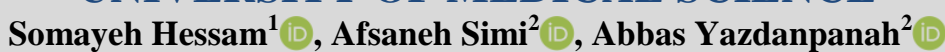 \\ ${ }^{I}$ Department of Health Services Administration, South Tehran branch, Islamic Azad University, Tehran, Iran. ${ }^{2}$ Department of Healthcare Management, Marvdasht Branch, Islamic Azad University, Marvdasht, Iran.
}

\section{ABSTRACT}

Objectives: The present research aimed to evaluate the position of health and safety system in multi-level strategic management of Shiraz University of medical science. This is a co relational-surveying study. Field information was collected via questionnaire. Statistical population consists of all staffs of Shiraz University of medical science (900 individuals).

Methods: To determine the sample size, Morgan Table was used so 269 individuals were selected by simple random method. To prevent drop out, 320 questionnaires were distributed and collected. As a result, 308 questionnaires were completed. Random sampling was used in the research. The instrument includes researcher-conducted questionnaire for evaluation of position of health and safety in multilevel management. The questionnaire's validity and reliability were confirmed. To analyze data, KolmogorovSmirnov, Pearson correlation coefficient, one sample T, independent T as well as variance analysis tests and SPSS version 20 were used.

Results: Results indicated that the safety system has an improper position in multilevel management of staffs in Shiraz University of medical science in addition; health system has a good position in multilevel management of staffs in Shiraz University of medical science.

Conclusion: It is suggested that subjects' related to multilevel management of staffs is considered.

Keywords: Health information management, family physician, treatment process.

\section{Article Info: Received 9 November 2017; Revised 10 January; Accepted 25 February, Available online 15 March 2018

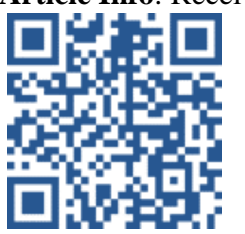 \\ Cite this article- \\ Hessam S, Simi A, Yazdanpanah A. The evaluation of the position of health and safety system in multi-level strategic management of staffs in Shiraz University of medical science. Universal Journal of Pharmaceutical Research. 2018; 3(1): 12-16. \\ DOI: http://doi.org/10.22270/ujpr.v3i1.R3 \\ Address for Correspondence \\ Somayeh Hessam, Department of Health Services Administration, South Tehran branch, Islamic Azad University, Tehran, Iran.} E-mail: somayehh59@yahoo.com

\section{INTRODUCTION}

All organizations wish to reach correct job performance via control of risks of occupational health and safety which is compatible with macro goals and policy of occupational safety and health ${ }^{1}$. This is done in form of strict rules, development of economic policies and other actions in direction of proper activities of occupational safety and health as well as the increasing attention of stakeholders to occupational safety and health ${ }^{2-7}$. It is necessary to deal with staffs' health, welfare and comfort as well as to apply strategies for adaptation with psychological and physical conditions. High level of staffs' health is effective on the growth and development of organizations and society. The role of management, as a main factor in promotion of health and welfare of the organization, is very important leading to organizational growth ${ }^{\mathbf{8 , 9}, 10}$. Strategic management has been considered as one of important factors in successful organizations. The process of strategic management consists of three stages: formulation, implementation and evaluation of strategy. The practices done in these stages are conducted in three levels of organizational hierarchy management including the whole company, current strategic unit and task level ${ }^{11}$. Multilevel planning is used to model non-centralized decision. Therefore, there are either several decision makers in several levels or a hierarchical organization and their decisions have reciprocal influence. In such planning, decision makers in different levels have related variables and targets ${ }^{12-}$ 14. ILO organizations are responsible for protection of workers against occupational diseases and events. Occupational diseases and events are due to ignorance of workers' health and safety. The main goal of ILO is to increase the chance of women and men in reaching 
qualified work under conditions of freedom, justice, safety and respect to human rights ${ }^{4,5,6}$. Such conditions were summarized under the term "qualified labor". Qualified labor is safe which is a positive and effective factor on economic growth and manufacture of products $^{10}$. According to statistics of international labor organization, 2.1 million people will die annually due to occupational diseases and events throughout the world. 250 million occupational events as well as 160 million occupational diseases are occurred in different regions of the world ${ }^{15}$. About 4 percent of national gross production is due to such diseases and events. Technological advances and competitive pressures cause rapid changes in work condition manufacture process and company structure. In this way, rules and regulations are not sufficient to resists against risks and an efficient management is required ${ }^{3}$. Technological advances and strong competition between industries caused rapid changes in managerial condition, process and system ${ }^{13,16,17}$. However, it is necessary but not sufficient to legislate rules for such changes as well as new risks. Organizations should solve problems occurring continuously for health and safety. They should find good solutions by dynamic managerial strategy ${ }^{10}$. Safety and health require an active management system because they cannot be supplied either collectively or individually or by compulsory regulations. The evidences for importance of safety management system in the high level of industrial safety and health suggest that an organizational cause has been involved in $46 \%$ of occupational events that lead to disability. According to studies, 50\% of occupational events are due to lack of an efficient safety management system ${ }^{33}$. A professional health and safety management system as well as environmental management should be created and kept by top managers and supervisors of the organization ${ }^{18}$. First, top management should try hard to grow and strengthen environmental management and professional health and safety management system ${ }^{19}$. It is necessary to solve such problem and reach achievements $^{18,19,20}$. One of such solutions is to increase healthy factors affecting the health and satisfaction of human source as well as to settle contradictory environmental factors through establishment of professional health and safety management and environmental management systems $^{29}$. The present research aims to evaluate the position of health and safety system in management.

\section{METHODS}

This is a co relational-surveying research. Statistical population includes all staffs in Shiraz University of medical science (900 individuals). To specify sample size, Morgan Table was used, thus 269 individuals were chosen by simply random sampling. To prevent drop out, 320 questionnaires were distributed and collected. As a result, 308 questionnaires were collected. Two researcher-conducted questionnaires of the position of safety system as well as the position of health system were used. Face validity of the questionnaire was evaluated by 5 professors and their opinions were applied ${ }^{21,22,23}$. In addition, the reliability of the questionnaire of safety system position was 0.90 as well as health system position was 0.83 using Cronbach alpha. Results were expressed by descriptive and inferential statistics as well as SPSS.

\section{RESULTS}

To evaluate normality of data distribution, Kolmogorov-Smirnov test was used as shown in Table 1. As shown in the Table 1, all components are normal due to significance level of 0.05 , thus parametric statistic is allowed. To evaluate research hypotheses, one sample T test was used as shown in Table $2^{24,25}$.

Table 1: Results of Kolmogorov-Smirnov test.

\begin{tabular}{lcc}
\hline Variable & $\mathbf{Z}$ & Sig. level \\
\hline $\begin{array}{l}\text { Safety system } \\
\text { position }\end{array}$ & 1.127 & 0.101 \\
$\begin{array}{l}\text { Health system } \\
\text { position }\end{array}$ & 1.119 & 0.120 \\
\hline
\end{tabular}

As seen in the Table 2, mean of health system position in multilevel management of staffs in Shiraz University of medical science is 3.67. Concerning $\mathrm{T}=-9.807$ and sig. level $=0.001$, it can be concluded that health system in multilevel management of staffs in Shiraz University of medical science has a proper position.

Table 2: Results of single sample T test.

\begin{tabular}{lcccc}
\hline Variable & Standard Mean & T & $\begin{array}{c}\text { Significance } \\
\text { level }\end{array}$ \\
\hline $\begin{array}{l}\text { Health system } \\
\text { position in multilevel } \\
\text { management }\end{array}$ & No.3 & 3.67 & 9.807 & 0.001 \\
$\begin{array}{l}\text { Safety system } \\
\text { position in multilevel } \\
\text { management }\end{array}$ & No.3 & 2.27 & -8.874 & 0.001 \\
\hline
\end{tabular}

In addition, mean of health system position in multilevel management is 2.27 . Concerning $\mathrm{T}=-8.874$ and Sig. level=0.001, it can be concluded that safety system in multilevel management does not have a proper position. There is a significant difference among views of individuals with different genders in terms of safety system and health system positions in multilevel management of staffs in Shiraz University of medical science.

Table 3: Results of independent $T$ test.

\begin{tabular}{lcccc}
\hline Variables & Groups & Mean & T & $\begin{array}{c}\text { Sig. } \\
\text { level }\end{array}$ \\
\hline $\begin{array}{l}\text { Safety system } \\
\text { position in multilevel } \\
\text { management }\end{array}$ & Men & 2.12 & 8.019 & 0.001 \\
\hline $\begin{array}{l}\text { Wealth system } \\
\text { position in multilevel } \\
\text { management }\end{array}$ & Men & 3.24 & 7.453 & 0.001 \\
\hline
\end{tabular}

T test was used to evaluate hypotheses as shown in Table 3. According to Table 3, there is a significant difference between views of men and women in terms of health and safety system position in multilevel management. Results also showed that women evaluated high level of health and safety system in multilevel management due to their high means. There is a significant difference among individual's views 
with different educations on safety system position in multilevel management.

Results were shown in Table 4. It is noteworthy that variances were homogeneous in all groups. As shown in the Table 4, there is a significant difference among individuals' views with different educations on safety system position in multilevel management (Sig. level $=0.015, \mathrm{~F}=4.203)^{26,27}$.

Table 4: Results of variance analysis test.

\begin{tabular}{cccccc}
\hline Groups & $\begin{array}{c}\text { Sum of } \\
\text { squares }\end{array}$ & $\begin{array}{c}\text { Freedom Root mean } \\
\text { degree }\end{array}$ & Fquares & & $\begin{array}{c}\text { Sig. } \\
\text { level }\end{array}$ \\
\hline Inter-group & 4.415 & 2 & 2.208 & 4.203 & 0.015 \\
Intra-group & 293.079 & 306 & 0.525 & & \\
$\quad$ Total & 297.494 & 308 & & & \\
\hline
\end{tabular}

Schaffe test was used to determine differences as shown in Table 5. According to results, there is a significant difference between views of individuals with diploma and lower degrees and those with M.A and higher degrees.

Table 5: Results of Schaffe test.

\begin{tabular}{|c|c|c|c|}
\hline Groups & $\begin{array}{c}\text { Diploma } \\
\text { and lower } \\
\text { degrees }\end{array}$ & $\begin{array}{c}\text { Associate } \\
\text { degree and } \\
\text { B. A }\end{array}$ & $\begin{array}{c}\text { M.A and } \\
\text { higher } \\
\text { degrees }\end{array}$ \\
\hline $\begin{array}{l}\text { Diploma and } \\
\text { lower degrees }\end{array}$ & & 0.290 & 0.016 \\
\hline $\begin{array}{l}\text { Associate degree } \\
\text { and B.A }\end{array}$ & & 0.271 & 0.365 \\
\hline $\begin{array}{l}\text { M.A and higher } \\
\text { degrees }\end{array}$ & & 0.242 & 0.025 \\
\hline
\end{tabular}

Mean opinion of each group on safety system position in multilevel management has been shown in Table 6 . There is a significant difference among views of people with different educations on health system position in multilevel management of staffs in Shiraz University of medical science ${ }^{28,29}$.

Table 6: Descriptive statistic of safety system position in multilevel management from views of groups with different educations.

\begin{tabular}{lcc}
\hline Groups & Mean & $\begin{array}{c}\text { Standard } \\
\text { deviation }\end{array}$ \\
\hline $\begin{array}{l}\text { M.A and higher } \\
\text { degrees }\end{array}$ & 3.01 & 0.743 \\
\hline $\begin{array}{l}\text { Associate degree } \\
\text { and B.A }\end{array}$ & 2.55 & 0.902 \\
\hline $\begin{array}{l}\text { Diploma and lower } \\
\text { degrees }\end{array}$ & 2.14 & 0.535 \\
\hline
\end{tabular}

Variance analysis test was used to evaluate this hypothesis as shown in Table 7. It is noteworthy that variances were homogenous in all groups. According to results of the fourth hypothesis, there is a significant difference among views of individuals with different educations about health system position in multilevel management (Sig. level=0.003, F=6.034). To specify differences, Schaffe test was used as shown in Table 8. As shown in results of Schaffe test, there was a significant difference between views of individuals with diploma and lower degrees and those with M.A and higher degrees. Mean views of each group on health system position in multilevel management have been shown in Table 9.

Table 7: Results of variance analysis test.

\begin{tabular}{cccccc}
\hline Groups & $\begin{array}{c}\text { Sum of } \\
\text { squares }\end{array}$ & $\begin{array}{c}\text { Freedom } \\
\text { degree }\end{array}$ & $\begin{array}{c}\text { Root mean } \\
\text { squares }\end{array}$ & F & $\begin{array}{c}\text { Sig. } \\
\text { level }\end{array}$ \\
\hline $\begin{array}{l}\text { Inter- } \\
\text { group }\end{array}$ & 8.126 & 2 & 4.063 & 6.034 & 0.003 \\
\hline $\begin{array}{l}\text { Intra- } \\
\text { group }\end{array}$ & 375.716 & 306 & 0.673 & & \\
\hline Total & 383.842 & 308 & & & \\
\hline
\end{tabular}

\section{DISCUSSION AND CONCLUSION}

The present research aimed to evaluate the position of health and safety system in multilevel strategic management in Shiraz University of medical science. This is an applied research as well as it is a co relational-surveying research. Field information was collected by the questionnaire. Statistical population includes all staffs of Shiraz University of medical science (900). To specify sample size, Morgan Table was used to choose 269 samples via simple random method.

Table 8: Results of Schaffe test.

\begin{tabular}{lccc}
\hline Groups & $\begin{array}{c}\text { Diploma } \\
\text { and } \\
\text { lower }\end{array}$ & $\begin{array}{c}\text { Associate } \\
\text { degree and B. } \\
\text { A }\end{array}$ & $\begin{array}{c}\text { M.A and } \\
\text { higher }\end{array}$ \\
\hline Diploma and lower & & 0.358 & $0.007^{*}$ \\
\hline $\begin{array}{l}\text { Associate degree } \\
\text { and B.A }\end{array}$ & & 0.060 \\
\hline $\begin{array}{l}\text { M.A and higher } \\
\text { degrees }\end{array}$ & & & \\
\hline
\end{tabular}

To prevent drop out, 320 questionnaires were distributed and collected. As a result, 308 questionnaires were collected. Random sampling was used in present research. The instrument used in the research was the researcher-conducted questionnaire of health and safety system position in multilevel management. The questionnaire's validity and reliability were evaluated and confirmed. KolmogorovSmirnov test, Pearson correlation coefficient, one sample $\mathrm{T}$ test, independent $\mathrm{T}$ test, variance analysis test as well as SPSS 20 were used to analyze data. Results indicated that mean safety system position in multilevel management of staffs of Shiraz University of medical science is 2.27 .

Table 9: Descriptive statistic of health system position in multilevel management from different educational groups.

\begin{tabular}{lcc}
\hline Groups & Mean & $\begin{array}{c}\text { Standard } \\
\text { deviation }\end{array}$ \\
\hline $\begin{array}{l}\text { M.A and higher } \\
\text { degrees }\end{array}$ & 3.88 & 0.780 \\
\hline $\begin{array}{l}\text { Associate degree } \\
\text { and B. A }\end{array}$ & 3.40 & 0.258 \\
\hline $\begin{array}{l}\text { Diploma and lower } \\
\text { degrees }\end{array}$ & 2.98 & 0.123 \\
\hline
\end{tabular}

Regarding $\mathrm{T}=-8.874$ and Sig. level=0.001, it can be concluded that safety system in multilevel management of staffs of Shiraz University of medical science did not have a proper position. Ismail et al., found in his 
research that safety system position was appropriate ${ }^{32}$. Therefore, the results of the first hypothesis in present research are not in agreement with their results. It seems that different organizations used in present research and in the research of Ismail et al., caused such disagreement. In addition ${ }^{32}$, Hu et al., found in his research that safety system has not had a proper position in industries. In this way, results of present research are in agreement with results of $\mathrm{Hu}^{31}$. To explore this hypothesis, it can be said that there is no proper safety in medical Science University of Shiraz because this organization has ignored the standards of safety. It seems that health issues have influenced on inappropriate position of safety. In addition, results of the present research indicated that mean health system position in multilevel management of staffs of Shiraz University of medical science was 3.67. Concerning $\mathrm{T}=$ - 9.807 and Sig. level=0.001, it can be said that health system in multilevel management of staffs of Shiraz University of medical science has a proper position. Pinto et al., found in his research that health position was proper in industries ${ }^{34}$. Ismail et al., evaluated factors affecting health and safety system ${ }^{32}$. They came up with the conclusion that appropriate planning and policy led to establishment of health and safety system, thus better application and effectiveness were resulted. Farshad et al., evaluated the role of HSE system in improvement of health, safety and environmental performances of organizations ${ }^{11}$. They concluded that health and safety indicators have been improved although the number of staffs, projects and work hours has increased ${ }^{11}$. Therefore, the results of the second hypothesis in present research are in agreement with results of Pinto et al., ${ }^{34}$, Ismail et al., ${ }^{32}$ and Farshad et al., ${ }^{11}$. To explore this hypothesis, it can be said that skillful human sources in field of health as well as top managers' attention to health position caused proper position of health system in multilevel management of Shiraz University of medical science. The results of present research indicated that there was a significant difference between views of women and men on health and safety system position in multilevel management. Furthermore, results showed that women evaluated high level of health and safety system in multilevel management due to their high means. Choudhry et al., noticed in their research that safety system was more important for men than women ${ }^{20}$. Therefore, results of the present research are not in agreement with their results. It seems that different organizations used in present research and that of Choudhry et al., caused such disagreement ${ }^{20}$. Tom et al., found that women evaluated more appropriately the position of safety and health system ${ }^{37}$. Therefore, the results of the second hypothesis in present research are in agreement with those of Tome et al. Results also showed that there was a significant difference among views of individuals with different educations on safety system position in multi-level management $(\mathrm{F}=4.203$, Sig. level=0.015). Results indicated that there was a significant difference between views of individuals with diploma and lower degrees and individuals with M.A or higher degrees. Ismail et al., found that individuals with higher education evaluated more positively safety system $^{32}$.
Arjomandi et al., found in their research that safety in work place of individuals with lower educations was less important ${ }^{1}$. The results of the fourth hypothesis in this research are in agreement with those of Ismail et al., ${ }^{32}$ and Arjomandi et al., ${ }^{1}$. To explore this hypothesis, it can be said that individuals with higher education evaluate properly the position of safety in multilevel management of Shiraz University of medical science because they have better understanding from safety and its position. Results of present research showed that there was a significant difference between views of individuals with different educations on health system position in multilevel management $(\mathrm{F}=6.034$, Sig. level=0.003). Results also indicated that there was a significant difference between views of individuals with diploma and lower degrees and those with M.A and higher degrees. Ismail et al., found in his research that individuals with higher education view health system in a higher position ${ }^{32}$. It can be expected that results of the fifth hypothesis in present research are consistent with those of Ismail et al. ${ }^{32}$ To explore this hypothesis, it can be said that individuals with higher education pay more attention to health showing their sensitivity to healthy issues. Therefore, individuals with higher education evaluate properly health system position in multilevel management of Shiraz University of medical science due their sensitivity to healthy issues. Results showed that safety system did not have a good position in multilevel management of staffs of Shiraz University of medical science whereas health position had a proper position multilevel management of staffs of Shiraz University of medical science ${ }^{34,35,36}$. Results revealed that women evaluated high level of safety and health system in multilevel management due their high means. According to results, there was a significant difference between views of individuals with diploma and lower degrees and those with M.A and higher education about safety system position. Results showed that there was a significant difference between views of individuals with diploma and lower degrees and those with M.A and higher degrees about health system position ${ }^{38}$.

\section{ACKNOWLEDGEMENTS}

The authors extend their thanks and appreciation to the Islamic Azad University, Tehran, Iran to provide necessary facilities for this work.

\section{AUTHOR'S CONTRIBUTION}

The manuscript was carried out, written, and approved in collaboration with all authors.

\section{CONFLICT OF INTEREST}

No conflict of interest associated with this work.

\section{REFERENCES}

1. Arjomandi R, Jozi SA, Noori J. Health, safety and environmental management in urban parks. J Science Tech Envir 2008; 1 .

2. Amirkafi M. The importance and rationale of multilevel model in social researches and Iranian sociological journal. 2006; 4, 38-71. https://doi.org/10.1016/j.jsp.2009.09.002 
3. Behroozi A. Professional health and safety management system, the first national congress of safety engineering and HSE management, Tehran, San'ati Sharif University, 2005.

4. Haghighi MA. The system of work relationships in the organization, Tehran: Termeh, 2000.

5. Khastar MA. Multilevel approach in studies of organization and management. Management Culture J 2009; 19, 163187.https://doi.org/10.1080/00208825.2015.1093797

6. Jozi SA, Atayi S. Evaluation and management of healthsafety risks in Iran Khodro factory by use of William Fyne method, the sixteenth national congress of environmental health, Tabriz University of medical science, health school, 2013.

7. Salighezadeh A. Health, safety and environment in civil projects, reducing the space between rules and implementation, the first national congress of health, safety and environment (HSE), Mahshahr, Islamic Azad University of Mahshahr, 2011

8. Faghihi A, Mansouri S. The necessity of considering and applying regulations and codes of safety and health in emergency department, the second national congress of emergency medicine, scientific association of emergency medicine in Iran, 2007.

9. Najdi MS, Saraj B, Organi M, Piri M. The role of safety and health in occupational security of workers of manufacturing contractor, the first international congress of health, safety and environment position in organizations, Isfahan, Tejarat Arvin Pishro Co, 2008

10. Shabani M, Nazari Sh. Instructions of occupational health and safety management systems, ILO-OSH 2001, ministry of labor and social affairs, assistance of work relationships regulation, general office of work inspection, 2006.

11. Farshad AA, Khosravi Y, Alizadeh S. Sh. The role of HSE management system in improvement of HSE performance of organizations, quarterly job health in Iran 2006; 3, 4 .

12. Rendal R, Ras Elizabeth, Altmayer M. Occupational stress, translated by gholamreza Khajehpour, Tehran: industrial management organization, 1998. https://doi.org/10.22089/SPSYJ.2018.4750.1508

13. Mirsepasi N. Management of human source and job relationships, a strategic attitude, Tehran, Shervin 1996. https://doi.org/10.5455/msm.2014.27.35-38

14. Ham'adi M. Modeling strategic management process with multilevel and multi-objective planning, the first national management congress, Shiraz, scientific management association, Shiraz University, 2010.

15. Bliese PD, Chan D, Ployhart RE. Multilevel methods: future directions in measurement, longitudinal analyses, and nonnormal outcomes, Organizational Research Methods. 2007; 10, 4, 551-563

https://doi.org/10.1177/1094428107301102

16. Jaccard M. The Objective is Quality: An introduction to performance and sustainability management systems. First ed. Switzerland, EPFL Press 2013; 156-59.

17. Chen, Chen Jui. Leadership effectiveness, Leadership style and employee readiness. Leadership Org Dev J. 2005; 26(4).https://doi.org/10.1108/01437730510600652

18. Chen Z, Clements-Croome DJ, Liu K, Sun L. An intelligent decision support system for well-being and energy-saving oriented building performance assessment, 2013

19. Chiarini A. Relationships between total quality management and Six Sigma inside European manufacturing companies: a dedicated survey. Int J Productivity Quality Man 2013; 11(2):179-94.

20. Choudhry RM, Fang D, Mohamed S. The nature of safety culture: A survey of the state-of-the-art. Safety sci 2007; 45(10): 993-1012.https://doi.org/10.1016/j.ssci.2006.09.003
21. De Celis ILR, de Bobadilla-Güémez SF, del Mar AlonsoAlmeida M, Velasco-Balmaseda E. Women's occupational health and safety management: An issue for corporate social responsibility. Safety Sci 2017; 91: 61-70. https://doi.org/10.1016/j.ssci.2016.07.019

22. Larson, Linda L. Internal auditors and job stress. Managerial Auditing J. 2004; 19(9): 1119-1130. https://doi.org/10.1108/02686900410562768

23. Fairborother, Kerry. Workplace dimensions, stress and job satisfaction. J Managerial Psych 2003; 18(1). https://doi.org/10.1108/02683940310459565

24. Hyde, Paula. Role redesign: new ways of working in the NHS. Personnel Review 2005; 34(6). https://doi.org/10.1108/00483480510623475

25. Hambidge SJ, Ross C, Shoup JA, Wain K, Narwaney K, Breslin K, McNeil Kolins, Rebecca. Seeing stars: human resources performance indicators in the National Health Service. Personnel Review 2005; 34(6): 634-647. https://doi.org/10.1108/00483480510623439

26. Miozza, Michael L, David C. Wyld. The Carrot or the Soft Stick? The perspective of American safety professionals on behavior and incentive-based protection programmers. Management Research News 2002; 25(11):23-41. https://doi.org/10.1108/01409170210783214

27. MM. Integration of data from a safety net health care system into the Vaccine Safety Datalink. Vaccine 2017. https://doi.org/10.1016/j.vaccine.2017.01.027

28. Leitão S, Greiner BA. Psychosocial, health promotion and safety culture management-are health and safety practitioners involved? Safety Sci 2017; 91: 84-92. https://doi.org/10.1016/j.ssci.2016.07.002

29. Elmholt KL, Sondrup A. Sustainable Enterprise Excellence from a SME Perspective. Master's thesis. Aarhus University, Business and Social Sciences, Department of Business Administration 2013. https://doi.org/10.1177\%2F1086026615575047

30. Fleischer M, Troege M. Organising product stewardship in large chemical companies. J Business Chemistry 2004; 1(2): 23-27.

31. $\mathrm{Hu} \mathrm{K}$, Rahmandad $\mathrm{H}$, Smith Jackson $\mathrm{T}$, Winchester $\mathrm{W}$. Factors influencing the risk of falls in the construction industry: a review of the evidence. Construction Management and Economy 2011; 29(4): 397-416. https://doi.org/10.1080/01446193.2011.558104

32. Ismail Z, Doostdar S, Harun Z. Factors influencing the implementation of a safety management system for construction sites. Safety Sci 2012; 50(3): 418-423. https://doi.org/10.1016/j.jcjq.2019.07.005

33. Ligade A, Thalange S. Occupational health and safety management system (OHSMS) model for construction industry. Int J Res Eng Techn 2013; 11: 395-399.

34. Pinto A, Nunes IL, Ribeiro RA. Occupational risk assessment in construction industry-Overview and reflection. Safety Sci 2011; 49(5): 616-624. https://doi.org/10.1016/j.ssci.2011.01.003

35. Ringdal, K. Recent developments in methods for multilevel analysis. Acta Sociologica 1992; 35: 235-243.

36. Stone. 2004. Human Resource Management

37. Tam CM, Zeng SX, Deng ZM. Identifying elements of poor construction safety management in China. Safety Sci 2004; 42(7): 569-586. https://doi.org/10.1016/j.ssci.2003.09.001

38. Yousef, Darvish A. Satisfaction with job security as a predictor of organizational commitment and job performance in a multicultural environment. Int J Manpower 1998; 19(3): 184-194. https://doi.org/10.1108/01437729810216694

39. Warren, Richard C. The empty company: morality and job security. Personal Review 1996; 25(6): 41-53. 